\title{
In vivo Activation of Wnt Signaling Pathway Enhances Cognitive Function of Adult Mice and Reverses Cognitive Deficits in an Alzheimer's Disease Model
}

\author{
Jessica Y. Vargas, ${ }^{1}$ Marco Fuenzalida, ${ }^{2}$ and Nibaldo C. Inestrosa ${ }^{1}$ \\ ${ }^{1}$ Centro de Envejecimiento y Regeneración, Departamento de Biología Celular y Molecular, Facultad de Ciencias Biológicas, Pontificia Universidad Católica \\ de Chile, Santiago 8331150, Chile, and ²Centro de Neurobiología y Plasticidad Cerebral, Departamento de Fisiología, Facultad de Ciencias, Universidad de \\ Valparaíso, Valparaíso 2360102, Chile
}

The role of the Wnt signaling pathway during synaptic development has been well established. In the adult brain, different components of Wnt signaling are expressed, but little is known about its role in mature synapses. Emerging in vitro studies have implicated Wnt signaling in synaptic plasticity. Furthermore, activation of Wnt signaling has shown to protect against amyloid- $\beta$-induced synaptic impairment. The present study provides the first evidence that in vivo activation of Wnt signaling improves episodic memory, increases excitatory synaptic transmission, and enhances long-term potentiation in adult wild-type mice. Moreover, the activation of $W n t$ signaling also rescues memory loss and improves synaptic dysfunction in APP/PS1-transgenic mice that model the amyloid pathology of Alzheimer's diseases. These findings indicate that Wnt signaling modulates cognitive function in the adult brain and could be a novel promising target for Alzheimer's disease therapy.

Key words: Alzheimer's disease; APP/PS1 mice; cognitive function; memory; synaptic plasticity; Wnt signaling

\section{Introduction}

Wnt ligands are secreted glycoproteins that participate as signaling molecules in diverse cellular processes (Nusse and Varmus, 2012). Wnt ligands signal through at least three different pathways: the canonical or $W n t / \beta$-catenin pathway and the two noncanonical $W n t / J N K$ and $W n t / \mathrm{Ca}^{2+}$ pathways (van Amerongen and Nusse, 2009). In addition to the important roles that Wnt signaling plays during nervous system development (Ciani and Salinas, 2005), Wnt ligands and other components of Wnt signaling are also expressed in most regions of the adult brain (Shimogori et al., 2004; Cerpa et al., 2008), but the role of this pathway in mature nervous system is still unclear.

Recent evidence suggests that Wnt ligands might modulate the efficacy of excitatory and inhibitory synaptic transmission (Budnik and Salinas, 2011; Park and Shen, 2012). Indeed, Wnt-7a ligand enhances synaptic transmission by increasing the probability of neurotransmitter release in cerebellar and hippocampal

\footnotetext{
Received Feb. 26, 2013; revised Nov. 8, 2013; accepted Nov. 30, 2013.

Author contributions: J.Y.V., M.F., and N.C.I. designed research; J.Y.V. performed research; J.Y.V., M.F., and N.C.I. analyzed data; J.Y.V., M.F., and N.C.I. wrote the paper.

This work was supported by the Comisión Nacional de Investigación Cientifica y Tecnológica (CONICYT Grant PFB12/2007 to N.C.I.), Fondo Nacional de Desarrollo Científico y Tecnológico (Grant 1120156 to N.C.I. and Grants 11090059 and 1130614 to M.F.), and Dirección de Investigación, Universidad de Valparaíso (Grant 46/2007 to M.F.), and the Fundación Gran Mariscal de Ayacucho (predoctoral fellowship to J.Y.V.).

The authors declare no competing financial interests.

Correspondence should be addressed to Dr. Nibaldo C. Inestrosa, Pontificia Universidad Católica de Chile, Alameda 340, Santiago 8331150, Chile. P0 Box 114-D. E-mail: ninestrosa@bio.puc.cl.

DOI:10.1523/JNEUROSCI.0862-13.2014

Copyright $\odot 2014$ the authors $\quad 0270-6474 / 14 / 342191-12 \$ 15.00 / 0$
}

synapse (Ahmad-Annuar et al., 2006; Cerpa et al., 2008). Wnt-5a ligand potentiates synaptic transmission by promoting the clustering of postsynaptic proteins and stimulating dendrite spine morphogenesis (Farias et al., 2009; Cuitino et al., 2010; VarelaNallar et al., 2010). Moreover, activation of Wnt signaling facilitates long-term potentiation (LTP), whereas blockage of Wnt signaling impairs it (Chen et al., 2006; Beaumont et al., 2007; Cerpa et al., 2011). This evidence led to the hypothesis that Wnt signaling might play a key role in the modulation of synaptic plasticity at mature synapses.

Additionally, deregulation of Wnt signaling has been implicated in Alzheimer's disease (AD) pathology (Anderton et al., 2000; De Ferrari and Inestrosa, 2000; Boonen et al., 2009). AD is a neurodegenerative disorder characterized by a progressive deterioration of the cognitive functions (Selkoe, 2001; Sheng et al., 2012). A remarkable feature in the brains of $\mathrm{AD}$ patients is the accumulation of amyloid- $\beta(\mathrm{A} \beta)$ peptide, which is associated with synaptic failure at early stages and neuronal loss at later stages of the disease (Selkoe, 2002). Several studies have revealed a relationship between loss of Wnt signaling and $\mathrm{A} \beta$-induced neurotoxicity (Zhang et al., 1998; Garrido et al., 2002; De Ferrari et al., 2003). In fact, blockage of $W n t / \beta$-catenin signaling by the Wnt antagonist Dickkopf-1 (Dkk1) increases neuronal death and synaptic loss induced by $\mathrm{A} \beta$ (Caricasole et al., 2004; Purro et al., 2012). Conversely, activation of $W n t / \beta$ catenin signaling by the $W n t-3 a$ ligand protects against $\mathrm{A} \beta$-induced cytotoxic insults (Alvarez et al., 2004; Shruster et al., 2011). Moreover, lithium treatment, a pharmacological activator of $W n t / \beta$ catenin signaling, has shown to reduce memory loss in APP/PS1 mice, a model of $\mathrm{AD}$ (Toledo and Inestrosa, 2010). 
Here, we evaluated for the first time the in vivo activation of Wnt signaling in the hippocampus of adult wild-type and APP/ PS1 mice. We found that chronic activation of Wnt signaling improves episodic memory, enhances basal excitatory synaptic transmission, and facilitates LTP in both types of mice. In summary, our results suggest that Wnt signaling not only plays a key role in synaptic plasticity of the mature nervous system, but is also a promising therapeutic target for $\mathrm{AD}$ treatment.

\section{Materials and Methods}

Animals. We used 7-month-old double transgenic APPswe/PSEN1DE9 mice (known as APP/PS1 in this study) and male age-matched wild-type littermates purchased from Jackson Laboratory. All animals were housed in the Animal House Facility of P. Universidad Católica de Chile in temperature-, humidity-, and light-controlled rooms, with food and water given ad libitum until the end of the treatments. Procedures for animal care, surgery, and slice preparation were in accordance with the guidelines for the care and use of laboratory animals adopted by the Society for Neuroscience.

Reagents. FOXY-5 (Formyl-MDGCEL) was obtained from Genemed Synthesis. JNK Inhibitor VII (TAT-TI-JIP ${ }_{153-163}$ ) was obtained from EMD Millipore. TCS-183 was obtained from Tocris Bioscience. 2-(2,7-Diethoxy9H-fluoren-9-ylidene) hydrazinecarboximidamide (WASP-1) was obtained from Chemdiv.

Infusion system preparation. Animals received bilateral chronic infusion into the CA1 hippocampal region with: (1) WASP-1 (Wntactivating small molecule), a potentiator of the canonical Wnt signaling that requires the activation of the signaling by endogenous $W n t-3 a$ ligand (Beaumont et al., 2007); (2) TCS-183, a competitive inhibitor of GSK-3 $\beta$ (Ser9) phosphorylation; (3) FOXY-5 (formylated Wnt-5a-derived hexapeptide), an activator of the noncanonical Wnt signaling that mimics the effect of Wnt-5a ligand (Safholm et al., 2006; Safholm et al., 2008); (4) TAT-TI-JIP, a cell-permeable JNK inhibitor, or (5) vehicle solution (artificial CSF, ACSF). Sterile reagents were diluted in ACSF and $0.01 \%$ DMSO to reach a final concentration of $5 \mu \mathrm{M}$ WASP-1, $300 \mu \mathrm{M}$ TCS-183, $50 \mu \mathrm{M}$ FOXY-5, and $1 \mu \mathrm{M}$ TAT-TI-JIP. These concentrations were chosen because they have been reported previously to be effective at activating or inhibiting Wnt signaling and producing in vitro changes in synaptic function (Beaumont et al., 2007; Peineau et al., 2007; Farias et al., 2009; Cuitino et al., 2010; Varela-Nallar et al., 2012). Chronic delivery was achieved via an Alzet osmotic mini-pump (1004; Durect). The assembly and preincubation of the mini-pump were performed according to the manufacturer's instructions. Briefly, mini-pumps were filled and connected to a double-brain infusion cannula (Plastics One) by catheter tubing (Durect) and a bifurcation cannula (Plastics One). The assembled infusion system was incubated in sterile saline at $37^{\circ} \mathrm{C}$ for $48 \mathrm{~h}$ before surgery.

Surgical procedures. For implantation of the infusion system, APP/PS1 and wild-type mice were anesthetized using $1.5-2.5 \%$ isoflurane. The head was shaved and the animal was placed in a small, animal stereotaxic frame (Stoelting) with nontraumatic ear bars to hold the skull in place. The skull was exposed from several millimeters anterior and posterior to bregma and $\lambda$. Bore holes were made above the left and right hippocampus (coordinates: $-2.46 \mathrm{~mm}$ anterior to the bregma, $\pm 1.0 \mathrm{~mm}$ lateral, $-1.5 \mathrm{~mm}$ relative to dura mater). A brain infusion cannula was stereotactically inserted into the hippocampus and fixed to the skull surface using binary dental cement. The mini-pump was inserted beneath the skin at the dorsum of the animal and the wound was closed using cyanoacrylate. Body temperature during anesthesia was maintained at $37^{\circ} \mathrm{C}$ by means of an isothermal heating pad. Mice were allowed to recover for 1 week before testing. Infusion was applied up to $21 \mathrm{~d}$.

Behavioral tests. For the memory flexibility test (Chen et al., 2000; Toledo and Inestrosa, 2010), infused animals were trained in a circular water maze ( $1.2 \mathrm{~m}$ diameter, opaque water, $50 \mathrm{~cm}$ deep, $\left.19-21^{\circ} \mathrm{C}\right)$. To evaluate the performance of the mice in the water maze, we used the visible platform test (four trials of $60 \mathrm{~s}$ top $+10 \mathrm{~s}$ on platform at the end of trials). For test episodic memory, each animal was trained for one pseudorandom location of the platform per day, with the platform hid- den $1 \mathrm{~cm}$ below water. Mice were trained for $4 \mathrm{~d}$, with a new platform location each day. Training was conducted up to 15 trials per day until the criterion of three successive trials with an escape latency of $<20$ s was reached. Data were collected using a video-tracking system for water mazes (HVS Imagen). For the novel object recognition test (Hillen et al., 2010), mice were habituated to the experimental room in the experimental cages for 3 consecutive days ( $30 \mathrm{~min}$ each time and $1 \mathrm{~h}$ on testing day). Testing was performed in $25 \mathrm{~cm} \times 25 \mathrm{~cm}$ opaque-walled cages. During the memory acquisition phase, mice were allowed to explore 2 identical objects (blue balls of $4 \mathrm{~cm}$ diameter) for $10 \mathrm{~min}$. After this, animals were returned to their home cages for $2.5 \mathrm{~h}$. During the memory retention phase, mice were exposed for $10 \mathrm{~min}$ to the presence of 1 familiar object and 1 new object (a yellow cube of $4 \mathrm{~cm}^{3}$ ). Cages were routinely cleaned with ethanol before each testing/habituating of mice. Object preferences were analyzed using Anymaze video-tracking software (Stoelting). Object preference index was determined by calculating the time spent near the novel object divided by the cumulative time spent with both familiar and novel objects.

Western blot. After the behavioral test, hippocampi of treated and control mice were dissected and homogenized in RIPA buffer using a Potter homogenizer. Samples were centrifuged at 14,000 r.p.m. at $4^{\circ} \mathrm{C}$ for $5 \mathrm{~min}$. Supernatants were used. Protein concentrations were determined using the BCA Protein Assay Kit (Pierce). Equal amounts of protein from each sample were resolved by $10 \%$ SDS-PAGE. Proteins were transferred to PVDF membranes and immunoblotting was done using mouse antiPSD-95, mouse anti-NR2B (Neuromab), rabbit anti-Syn-1, mouse anti- $\beta$-catenin, mouse anti-c-myc, mouse anti-CaMKII, mouse antiphospho-CaMKII (Santa Cruz Biotechnology), rabbit anti-Syp, rabbit anti-GSK-3 $\beta$, rabbit anti-phospho-Ser9-GSK-3 $\beta$, rabbit antiJNK, rabbit anti-phospho-JNK, and mouse anti- $\beta$-actin (Cell Signaling Technology) antibodies. Immunoreactivity was visualized using a chemiluminescent substrate ( Thermo Fisher Scientific) and optical densities were quantified using ImageJ software.

Electrophysiological recording. Slices preparation and field electrophysiological recordings were performed as described previously (Cerpa et al., 2008; Bonansco et al., 2011). Hippocampal slices were prepared from mice that had been infused for 15 to $20 \mathrm{~d}$. Animals were decapitated and the brain was removed and immediately submerged in cold ACSF $\left(\sim 4^{\circ} \mathrm{C}\right)$ bubbled with carbogen $\left(95 \% \mathrm{O}_{2}, 5 \% \mathrm{CO}_{2}\right)$. Coronal slices from the hippocampus $(250 \mu \mathrm{m})$ were cut using a Vibroslice microtome (World Precision Instruments) and incubated in carbogen-bubbled ACSF for $1 \mathrm{~h}$ at room temperature $\left(22-24^{\circ} \mathrm{C}\right)$. Slices were transferred into a chamber and superfused $\left(3 \mathrm{ml} / \mathrm{min}\right.$ at $\left.22-26^{\circ} \mathrm{C}\right)$ with gassed ACSF. In all experiments, picrotoxin $(10 \mu \mathrm{M})$ was added to ACSF perfusion solution to suppress inhibitory GABA type-A transmission. Recording of field EPSPs (fEPSPs) was performed with a glass pipette (2-4 M $\Omega$ filled with ACSF), placed in the middle of stratum radiatum of CA1, and connected to an AC amplifier (P-5 series; Grass) with gain 10,000×, low-pass filter $3.0 \mathrm{kHz}$, and high-pass filter $0.30 \mathrm{~Hz}$. A bipolar concentric electrode (platinum/iridium, $125 \mu \mathrm{m}$ outer diameter; FHC) was placed in the stratum radiatum 100-200 $\mu \mathrm{m}$ away from the recording site. Schaeffer collateral fibers were activated by bipolar cathodic stimulation generated by a stimulator (Master 8; AMPI) connected to an isolation unit (Isoflex; AMPI). Electric pulses $(50 \mu \mathrm{s}, 0.3 \mathrm{~Hz}, 20-100 \mu \mathrm{A})$ were applied on Schaeffer collaterals. Basal excitatory synaptic transmission was measured by using an input/output curve protocol (Hsia et al., 1998) consisting of eight stimuli ranging from 200 to $900 \mu \mathrm{A}$ (interval between stimuli $10 \mathrm{~s})$. To elicit LTP in the adult mice, we used a high-frequency stimulation (HFS) protocol (Hu et al., 2006; Maglio et al., 2006) consisting of 2 trains of $100 \mathrm{~Hz}$ for $500 \mathrm{~ms}$ separated by $1 \mathrm{~s}$ applied after at least $15 \mathrm{~min}$ of stable baseline recordings. Analyses of fEPSPs were performed with Clampfit 10 (pCLAMP; Molecular Devices) software.

Statistical analysis. Data were expressed as mean \pm SE of the values from the number of experiments, as indicated in the corresponding figures. Data were evaluated statistically using Student's $t$ test or ANOVA with Tukey's post hoc test to determine differences among more than two groups. Differences were considered significant at ${ }^{*} p<0.01$ or ${ }^{* *} p<0.001$. 
A
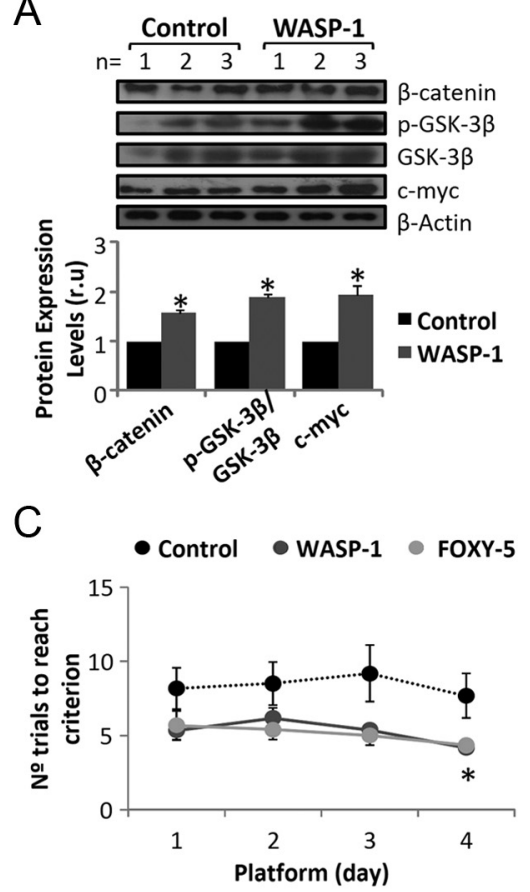

$\mathrm{F}$

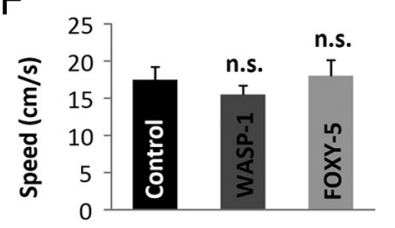

G

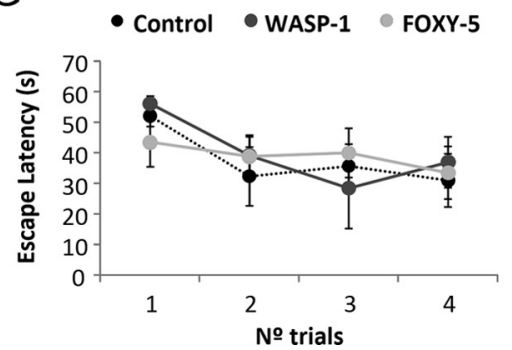

B

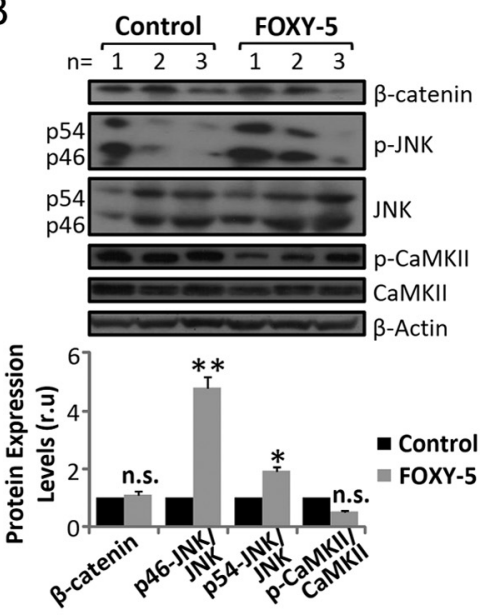

D

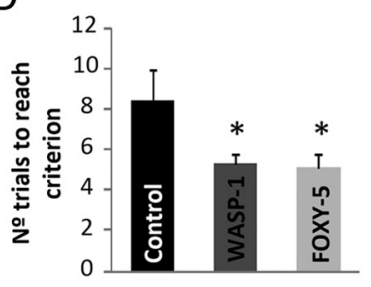

E

Control

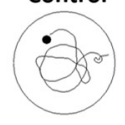

WASP-1

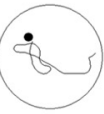

$\mathrm{H}$

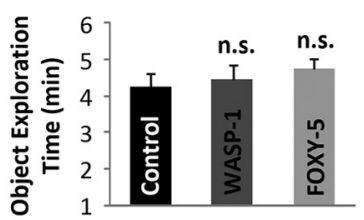

FOXY-5

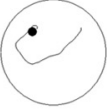

I

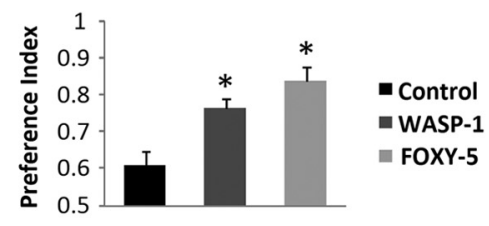

Figure 1. In vivo administration of WASP-1 and FOXY-5 activate Wnt signaling and improve memory in adult wild-type mice. $\boldsymbol{A}-\boldsymbol{B}$, Immunoblotting for Wnt pathway proteins of hippocampal homogenates from WASP-1 ( $n=3)$, FOXY-5 $(n=3)$, and control $(n=3)$ mice. $A$, Top, Western blot of control and WASP-1-treated mice for the canonical Wnt signaling proteins $\beta$-catenin, GSK-3 $\beta$, and its inhibitory isoform phospho-Ser-9 (p-GSK-3 $\beta$ ), and the target gene c-myc. Bottom: Quantification of protein band intensities after $\beta$-actin normalization. Graphic shows fold increase versus control. $\boldsymbol{B}$, Top, Western blot of control and FOXY-5treated mice for $\beta$-catenin and the noncanonical Wnt signaling proteins JNK and CaMKII and their corresponding phosphorylated isoforms. Bottom, Quantitative analysis as described in A. C $-\mathbf{G}$, Behavioral performance of WASP-1 $(n=7)$, FOXY-5 $(n=6)$, and control $(n=7)$ mice in the memory flexibility test. $\boldsymbol{C}$, Daily progression on each platform location. $\boldsymbol{D}$, Comparison of the mean number of trials necessary to reach criterion. Graphic shows the mean value of the $4 \mathrm{~d}$ of testing for each group. $\boldsymbol{E}$, Representative tracks of the last day of testing showing different swimming strategies among groups. $\boldsymbol{F}$, Comparison of the mean swim speed showing no significant differences among groups. $\mathbf{G}$, Comparison of the escape latency in the visible platform test showing no significant differences among groups for any trial. $\boldsymbol{H}-\boldsymbol{I}$, Behavioral performance of WASP-1 $(n=7)$, FOXY-5 $(n=6)$, and control $(n=7)$ mice in the novel object recognition test. $\boldsymbol{H}$, Total object exploration time during acquisition memory phase of the test showing no significant differences among groups. I, Comparison of the preference index for a novel object during retention memory phase of the test. Preference index was calculated as the time spent exploring the new object compared with both objects. n.s., No significant differences.

\section{Results}

WASP-1 and FOXY-5 activate Wnt signaling in vivo

To study the role of Wnt signaling in the cognitive function of adult mice, we used WASP-1, a potentiator of Wnt/ $\beta$-catenin signaling (Beaumont et al., 2007), and FOXY-5, an activator of both Wnt/JNK and $W n t / \mathrm{Ca}^{+2}$ signaling (Farias et al., 2009; Cuitino et al., 2010; Varela-Nallar et al., 2012). Administration of WASP-1, FOXY-5, or ACSF (control) was performed into the hippocampus of infused animals. Chronic treatment with WASP-1 increases hippocampal levels of phospho-Ser9-GSK$3 \beta, \beta$-catenin, and c-myc (Fig. $1 A$ ). The WASP-1-induced increase of phosphoSer9-GSK-3 $\beta$, an inhibitory form of glycogen synthase kinase- $3 \beta$ (GSK-3 $\beta$, a component of the $\beta$-catenin destruction complex) might lead to an increment in the levels of $\beta$-catenin that could account for the increment of c-myc, a target gene of $W n t / \beta$-catenin signaling. The occurrence of these events suggests that infusion of WASP-1 in vivo activates $W n t / \beta$-catenin signaling. Conversely, the intrahippocampal infusion of FOXY-5 increases JNK phosphorylation without changing the phosphorylation state of the $\mathrm{Ca}^{2+}$-sensitive protein calmodulin-dependent protein kinase II (CaMKII) or $\beta$-catenin levels (Fig. $1 B$ ), indicating that FOXY-5 treatment activates $W n t / J N K$ signaling in vivo.

\section{WASP-1 and FOXY-5 improve episodic memory}

Recent reports have found that activation of $W n t / \beta$-catenin signaling can modulate amygdala-dependent fear memory formation (Maguschak and Ressler, 2008, 2011). We hypothesized that activation of Wnt signaling could also participate in hippocampal-dependent learning and memory processes. To determine whether WASP-1 and FOXY-5 have an effect on memory, we compared memory acquisition and retention abilities of treated and control wild-type (WT) mice in tests for episodic memory. We first assessed the performance of mice in a visible platform test, a variant of the Morris water maze, to test for baseline differences of visual and motivational performance (Okun et al., 2010). WASP-1, FOXY-5, and control mice exhibit similar escape latencies for the visible platform test (Fig. $1 G$ ), suggesting no baseline differences in vision or motivation among groups. To measure hippocampus-dependent episodic memory, we tested the mice in a memory flexibility test (Chen et al., 2000). Animals treated with WASP-1 and FOXY-5 show a reduction in the number of trials to reach criterion compared with control mice (Fig. 1C). The average of the $4 \mathrm{~d}$ of training indicates that WASP- 1 and FOXY- 5 treatments cause a significant reduction in the number of trials to reach criterion (Fig. $1 D$ ). Indeed, WASP-1- and FOXY-5-treated animals showed improved strategies to reach the platform compared with control mice (Fig. 1E). The fact that there are no differences in swim 
speed among the WASP-1, FOXY-5, and control groups (Fig. $1 F$ ) indicates that the reduction in the number of trials to reach criterion observed in WASP-1- and FOXY-5-treated mice is due to memory improvement.

We also tested the mice for novel object recognition to evaluate nonspatial short-term memory of a novel object in a familiar setting (Bevins and Besheer, 2006). No significant difference in total exploration time during object familiarization among control, WASP-1-, and FOXY-5-treated mice (Fig. $1 H$ ) was observed. However, WASP-1- and FOXY-5treated mice exhibit significantly higher preference for a novel object than control mice during the memory retention phase of the test (Fig. 1I).

In summary, these results suggest that chronic Wnt signaling activation enhances short-term memory retention, improving episodic memory in adult mice. This is consistent with previous evidence indicating that an increase of hippocampal levels of Wnt ligands would serve to enhance consolidation of new memories (Tabatadze et al., 2012).

\section{WASP-1 and FOXY-5 enhance synaptic function and plasticity}

Recent studies have implicated Wht signaling in synaptic plasticity of the mature nervous system (Inestrosa and Arenas, 2010; Budnik and Salinas, 2011). Electrophysiological recordings of hippocampal slices or cultured neurons suggest that Wnt ligands can enhance synaptic transmission and increase the magnitude of LTP (Ahmad-Annuar et al., 2006; Chen et al., 2006; Beaumont et al., 2007; Cerpa et al., 2008; Cuitino et al., 2010; VarelaNallar et al., 2010; Cerpa et al., 2011). Here, we have evaluated the effect of in vivo Wnt signaling activation on excitatory synaptic transmission and LTP in adult WT mice. First, we tested whether WASP-1 and FOXY-5 treatments could change basal excitatory synaptic transmission using an input/output analysis. Because activation of Wnt signaling has been shown to increase the number of excitatory synapses (Farias et al., 2009; Gogolla et al., 2009; VarelaNallar et al., 2010; Ciani et al., 2011), we hypothesized that WASP-1 and FOXY-5 treatments would enhance synaptic responses if the increase in synapse density corresponds to the formation of functional synapses. Therefore, we compared fEPSP input/output relations in WASP-1- and FOXY-5-treated mice versus control mice (Fig. 2). In Figure $2 A$, superimposed field responses of WASP-1, FOXY-5, and control animals are shown. For equal fiber volley amplitudes (arrow), the elicited synaptic responses were larger in WASP-1- and FOXY-5-treated mice (Fig. 2A). As Figure $2 B$ shows, for given fiber volley amplitudes, comparatively more robust synaptic responses are exhibited by WASP-1- and FOXY-5-treated mice than control mice. Because the fiber volley is a measure of the number of axons activated
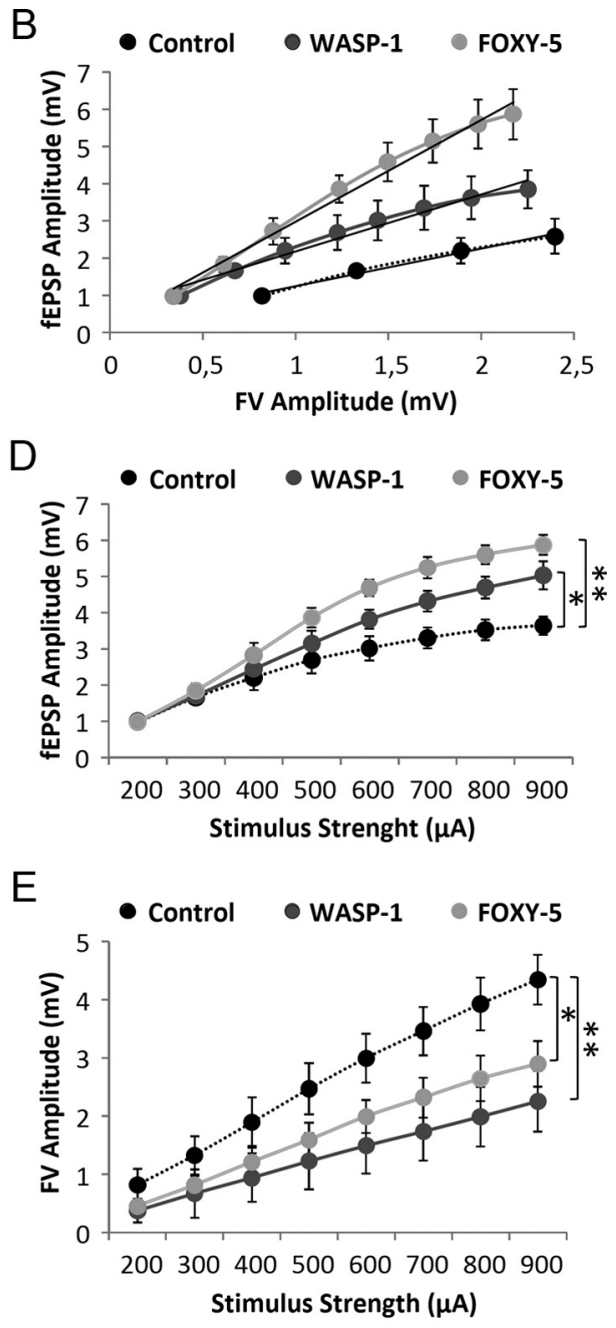

Figure 2. Wnt activators enhance basal excitatory synaptic transmission in adult wild-type mice. $\boldsymbol{A}-\boldsymbol{E}$, Field recordings of hippocampal slices from WASP-1 $(n=10)$, FOXY-5 $(n=10)$, and control $(n=10)$ mice. $A$, Representative synaptic responses for equal fiber volley (FV) amplitude (black arrow). $\boldsymbol{B}$, Correlation of fEPSP and FV amplitudes for each group. Black lines are the ssion line for fEPSP (output) and FV (input). The correlation coefficients $\left(R^{2}\right)$ in the control, WASP-1, and FOXY-5 mice wer otted lines indicate FV amplitude of $1 \mathrm{mV}$. D, Plot of fEPSP amplitude versus stimulus intensity (from 200 to $900 \mu \mathrm{A}$ ). $\boldsymbol{E}_{\text {, Plot of FV }}$ amplitude versus stimulus intensity (from 200 to $900 \mu \mathrm{A}$ ).

(Hsia et al., 1998), the observed increase in the magnitude of fEPSP amplitude suggests that WASP- 1 and FOXY-5 treatments enhance synaptic strength between CA3-CA1 hippocampal connection. Indeed, WASP-1 and FOXY-5 treatments display enhanced input/output relationship in response to increasing stimulus intensity (Fig. 2D). Measurements of fEPSP amplitude showed that WASP-1- and FOXY-5-treated mice exhibit a significant increase of basal synaptic transmission compared with control mice (Fig. 2C,D). For example, at the highest stimulus intensity tested $(900 \mu \mathrm{A})$, the mean value of fEPSPs were $5.04 \pm$ $0.22,5.86 \pm 0.23$, and $3.84 \pm 0.28 \mathrm{mV}$ in WASP- $1(n=10$ slices $/ 6$ mice), FOXY-5 ( $n=10$ slices $/ 5$ mice), and control ( $n=10$ slices/7 mice) animals, respectively. As shown in Figure $2 C$, for several stimulus intensities, control mice exhibit synaptic responses of similar amplitude to that of the fiber volley, whereas WASP-1 and FOXY-5 treatments evoke synaptic responses of larger amplitude than the accompanying fiber volley. In fact, the fiber volley amplitude elicited by a given stimulus intensity are decreased in WASP-1- and FOXY-5-treated mice (Fig. 2E), suggesting that 
A

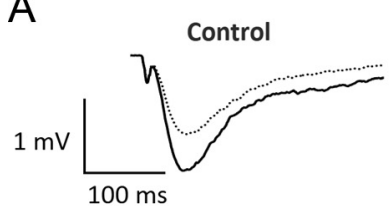

B

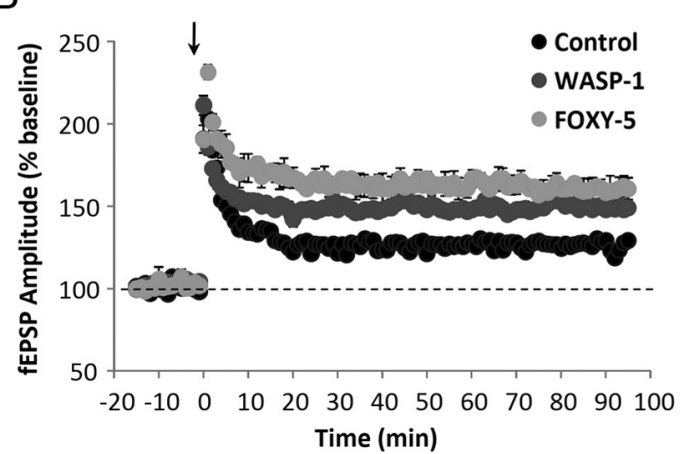

WASP-1

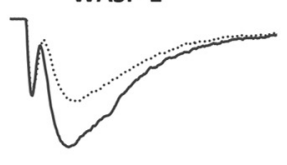

C

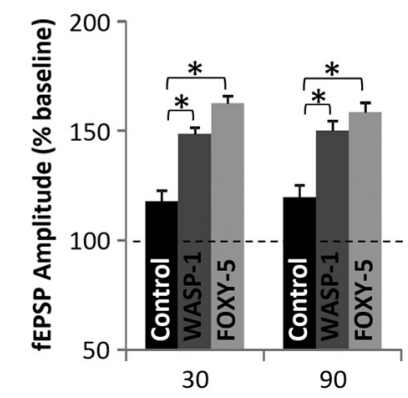

Time after HFS (min)

Figure 3. Wnt activators enhance hippocampal LTP in adult wild-type mice. $\boldsymbol{A}-\boldsymbol{C}$, Field recordings of hippocampal slices from WASP-1 ( $n=9)$, FOXY-5 $(n=9)$, and control $(n=10)$ mice. $A$, Average traces of fEPSP before (dotted lines) and after (filled lines) HFS. $B$, Plot of fEPSP amplitude versus time (from $10 \mathrm{~min}$ before HFS (arrow) up to $90 \mathrm{~min}$ after). Graphic shows percent increase of fEPSP amplitude compared with baseline (dotted line). C, Comparison of mean fEPSP amplitude among groups at 30 or 90 min after HFS showing percent increase versus baseline.

less axon fibers than in control mice should be activated to elicit synaptic responses of similar amplitude. Together, these findings strongly suggest that in vivo activation of Wnt signaling induces an enhancement of the basal excitatory synaptic strength.

Considering the effects found on behavioral performance (Fig. $1 C-I$ ) and the fact that chronic activation of Wnt signaling increases the efficacy of basal synaptic transmission (Fig. 2), we next investigated the effect of WASP- 1 and FOXY-5 treatments on synaptic plasticity. Using an HFS protocol, we studied the effect of WASP-1 and FOXY-5 on hippocampal LTP. In Figure $3 A$, superimposed field responses of WASP-1- and FOXY-5treated mice show that HFS evokes fEPSP of larger amplitude than in control mice. Because the fEPSPs monitored for $10 \mathrm{~min}$ before HFS were generally stable, their mean value was determined as the baseline (Fig. $3 B, C$, dotted line). A robust potentiation of the synaptic responses were produced and maintained for $>90$ min after HFS in control $(n=10$ slices/7 mice) animals (Fig. 3B). Interestingly, fEPSP amplitudes evoked by the same paradigm were comparatively larger in WASP-1-treated $(n=9$ slices $/ 6$ mice) and FOXY-5-treated $(n=9$ slices $/ 5$ mice $)$ mice than in control animals (Fig. $3 B$ ). Moreover, this effect was sustained for $>1 \mathrm{~h}$ after LTP induction (Fig. $3 B$ ). Therefore, the LTP magnitude at 30 or 90 min after HFS was significantly enhanced in WASP-1 ( $148.12 \pm 2.68 \%$ and $147.94 \pm 2.04 \%$, respectively) and FOXY -5 (162.44 $\pm 1.94 \%$ and $158.44 \pm 5.02 \%$, respectively) mice than in control $(121.54 \pm 2.24 \%$ and $129.18 \pm 1.90 \%$, respectively) mice (Fig. 3C). Increased potentiation of fEPSPs in both WASP-1 and FOXY-5 treatments compared with control suggest that chronic activation of Wnt signaling facilitates longterm synaptic plasticity at the Schaffer collateral-CA1 synapses.

To determine possible downstream effectors of the Wnt pathway involved in the effects elicited by WASP- 1 and FOXY- 5 treatments on hippocampal LTP, we performed chronic infusions of Wnt inhibitors in the presence and absent of WASP-1 or FOXY-5. We used TCS-183, a competitive inhibitor of the inactivating GSK- $3 \beta$ phosphorylation, to block the $W n t / \beta$-catenin pathway. In Figure $4 A$, representative field responses of WASP-1 $(n=9$ slices/6 mice), TCS-183 $(n=6$ slices $/ 3$ mice), and TCS-183 + WASP-1 $(n=6$ slices/3 mice)-treated mice before and after HFS are shown. The coinfusion of TCS-183 + WASP-1 significantly decreases LTP magnitude compared with the infusion of WASP-1 alone (Figs. 4AC). In fact, LTP magnitude at 30 or $60 \mathrm{~min}$ after HFS was significantly reduced in TCS-183 + WASP-1 (111.23 $\pm 8.96 \%$ and $102.21 \pm 5.97 \%$, respectively) compared with WASP-1 (148.12 $\pm 2.68 \%$ and $147.89 \pm 1.76 \%$, respectively) mice (Fig. 4C). Interestingly, infusion of TCS- 183 alone was able to block LTP, indicating that blocking the inhibition of endogenous GSK- $3 \beta$ is sufficient to impair hippocampal LTP (Fig. $4 A-C$ ), which is consistent with previous evidence showing that inhibition of GSK-3 $\beta$ facilitates the induction of LTP (Hooper et al., 2007; Peineau et al., 2007). Conversely, to establish a possible effector implicated in the effect of FOXY-5 on LTP, we used the JNK inhibitor TAT-TI-JIP because we found that chronic treatment with FOXY-5 activates the $W n t / J N K$ pathway but not the $W n t / \mathrm{Ca}^{2+}$ pathway (Fig. $1 B$ ). In Figure $4 D$, representative field responses of FOXY $-5(n=$ 9 slices $/ 5$ mice), TAT-TI-JIP ( $n=6$ slices $/ 3$ mice), and TAT-TIJIP + FOXY-5 ( $n=5$ slices $/ 3$ mice $)$-treated mice before and after HFS are shown. Both treatments, TAT-TI-JIP alone and TAT-TIJIP + FOXY-5, significantly decreased LTP magnitude compared with FOXY-5 treatment (Figs. $4 D-F$ ). Indeed, LTP magnitude at 30 or 60 min after HFS was significantly reduced in TAT-TI-JIP $(120.94 \pm 3.52 \%$ and $116.29 \pm 5.43 \%$, respectively) and TATTI-JIP + FOXY-5 (109.37 $\pm 4.27 \%$ and $108.42 \pm 1.62 \%$, respectively) mice compared with FOXY-5 (162.44 $\pm 1.94 \%$ and $166.67 \pm 5.17 \%$, respectively) mice (Fig. $4 E$ ). The fact that infusion of TAT-TI-JIP alone causes blockage of LTP indicates that JNK activity is necessary for LTP induction, as proposed previously (Chen et al., 2005; Seo et al., 2012). Interestingly, coinfusion of TAT-TI-JIP did not block the effect of WASP-1 on LTP and the coinfusion of TCS-183 did not cause significant changes over the effect of FOXY-5 (data not shown). These results suggest that GSK- $3 \beta$ could be a downstream effector of WASP-1, but not FOXY 5 , whereas JNK could be mediating the in vivo effects of FOXY-5, but is not involved in the effects of WASP-1. Together with the data shown in Figure 1, $A$ and $B$, these findings indicate that WASP-1 selectively activates $W n t / \beta$-catenin pathway, whereas FOXY-5 activates the $\mathrm{Wnt} / \mathrm{Ca}^{2+}$ pathway.

Our findings are consistent with previous in vitro studies indicating that Wnt ligands can modulate synaptic transmission and plasticity (Inestrosa and Arenas, 2010; Budnik and Salinas, 2011). Here, we have demonstrated that in vivo activation of Wnt signaling increases the synaptic efficacy of excitatory synapses and reduces the threshold for LTP induction in the adult hippocampus. Moreover, we show here that endogenous activation of Wnt signaling is required for the induction and maintenance of hippocampal LTP, because infusion of Wnt inhibitors alone was able to impair LTP without affecting posttetanic potentiation (Fig. $4 B, C$ ).

Because the activation of Wnt signaling can regulate the expression of genes that are involved in memory and synaptic plas- 
A

WASP-1

TCS-183
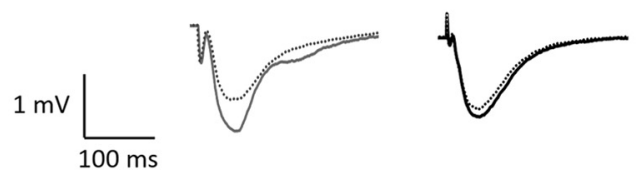

B

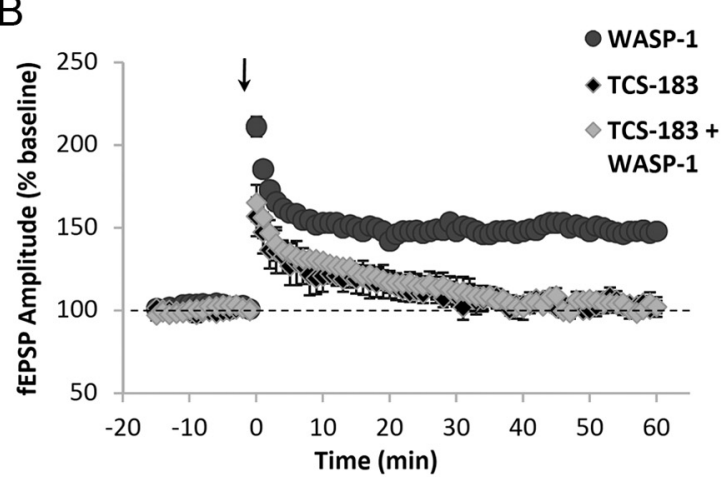

D
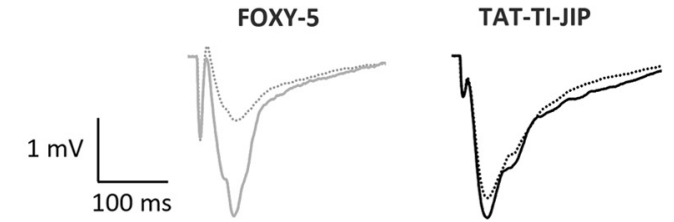

E

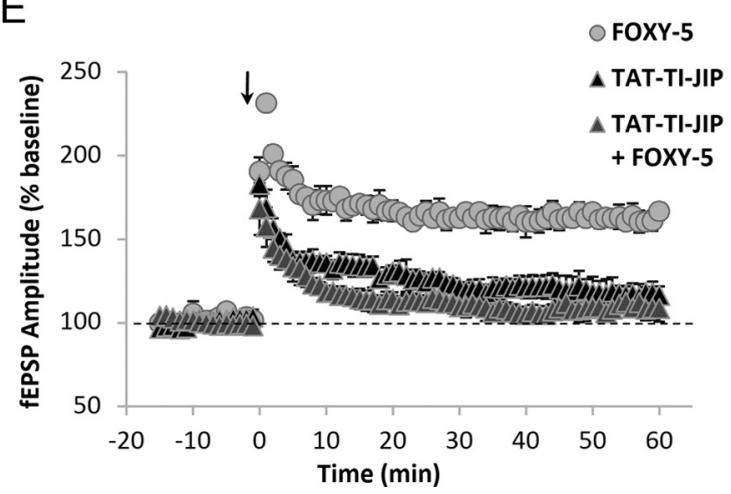

TCS-183 + WASP-1

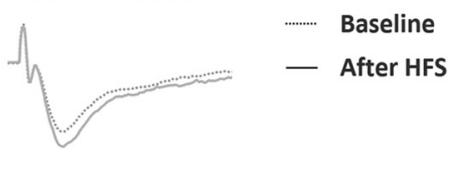

C

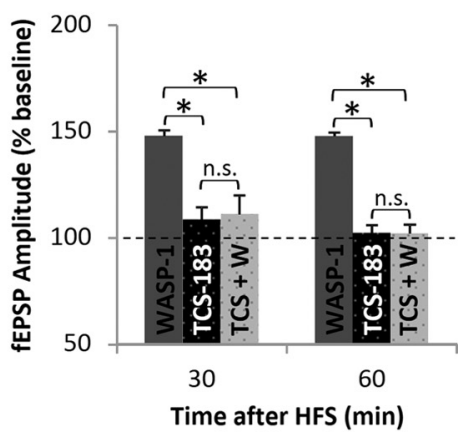

TAT-TI-JIP + FOXY-5

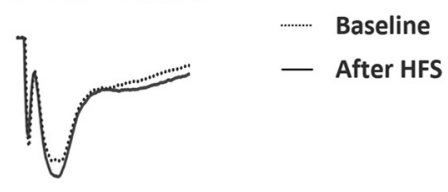

F

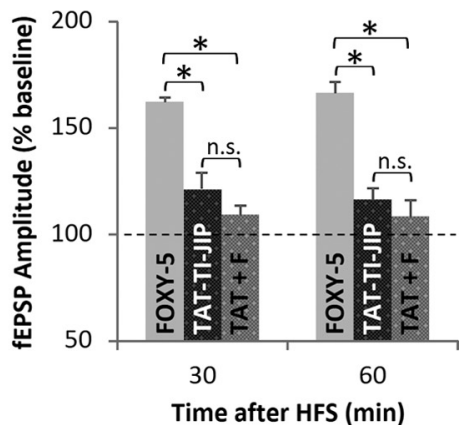

Figure 4. Inhibition of Wnt pathway impairs hippocampal LTP in adult wild-type mice. $\boldsymbol{A}-\boldsymbol{C}$, Field recordings of hippocampal slices from WASP-1 $(n=9)$, TCS-183 $(n=6)$, and TCS-183 + WASP-1 $(n=6$ )-treated mice. A, Representative traces of fEPSP before (dotted lines) and after (filled lines) HFS. B, Time course of normalized fEPSP amplitude from 15 min before HFS (arrow) up to $60 \mathrm{~min}$ after. Graphic shows percent increase of fEPSP amplitude compared with baseline (dotted line). C, Comparison of mean fEPSP amplitude among treated mice groups at 30 or 60 min after HFS showing percent increase versus baseline. (D-F) Field recordings of hippocampal slices from FOXY-5 $(n=9)$, TAT-TI-JIP $(n=6)$, and TAT-TI-JIP + FOXY-5 $(n=5)$-treated mice. $\boldsymbol{D}$, Representative traces of fEPSP before (dotted lines) and after (filled lines) HFS. E, Time course of normalized fEPSP amplitude as described in B. $\boldsymbol{F}$, Comparison of mean fEPSP amplitude as described in $\boldsymbol{C}$.

ticity (Arrazola et al., 2009), it is possible that the effects of WASP-1 and FOXY-5 on hippocampal LTP could be mediated by the modulation of gene expression. In fact, previous studies have shown that late phase LTP (1-LTP) requires protein translation and/or gene transcription (Kelleher et al., 2004; Raymond, 2007; Richter and Klann, 2009). Using acute hippocampal slice preparation, we tested the effects of WASP-1 and FOXY-5 on the LTP magnitude in the presence or absence of a gene transcription inhibitor, actinomycin-D (AMD, $25 \mu \mathrm{M})$, and a protein synthesis inhibitor, cycloheximide $(\mathrm{CH}, 40 \mu \mathrm{g} / \mathrm{ml})$. Consistent with previous reports, we found that perfusion of $\mathrm{AMD}$ or $\mathrm{CH}$ alone affects 1-LTP maintenance (Table 1). Interestingly, transcription inhibition only impairs FOXY-5-induced LTP at 120 min after HFS application, but does not affect WASP-1-induced LTP at any time assayed; however, translation inhibition impairs LTP induced by either WASP-1 or FOXY-5 treatments only at $120 \mathrm{~min}$ after HFS application (Table 1). These results indicate that the effect of WASP-1 on the maintenance of 1-LTP is dependent on protein synthesis, but does not involve gene transcription, whereas the effect of FOXY-5 requires both.

\section{WASP-1 and FOXY-5 increase synaptic protein levels}

Previous studies have shown that activation of Wnt signaling promotes the assembly of presynaptic and postsynaptic sites in developing and mature synapses (Ciani and Salinas, 2005; Farias et al., 2010). Indeed, canonical Wnt ligands have been implicated in the assembling of presynaptic proteins (Inestrosa and Arenas, 2010). Therefore, Wnt-7a ligand induces the clustering of the 
Table 1. Effect of transcription and translation inhibitors on hippocampal LTP enhancement induced by WASP-1 and FOXY-5 treatments

\begin{tabular}{|c|c|c|c|c|c|c|c|c|c|}
\hline \multirow[b]{3}{*}{ Time after HFS (min) } & \multicolumn{9}{|l|}{ Treatments } \\
\hline & \multicolumn{3}{|l|}{ CONTROL } & \multicolumn{3}{|l|}{ WASP-1 } & \multicolumn{3}{|l|}{ FOXY-5 } \\
\hline & Vehicle & AMD & $\mathrm{CH}$ & Vehicle & AMD & $\mathrm{CH}$ & Vehicle & AMD & $\mathrm{CH}$ \\
\hline 30 & $134.6 \pm 4.8 \%$ & $131.1 \pm 7.1 \%$ & $139.1 \pm 3.1 \%$ & $145.6 \pm 2.3 \%$ & $142.4 \pm 3.4 \%$ & $144.7 \pm 2.1 \%$ & $153.9 \pm 3.1 \%$ & $159.6 \pm 4.2 \%$ & $151.8 \pm 2.6 \%$ \\
\hline 60 & $128.8 \pm 5.2 \%$ & $117.3 \pm 7.6 \%$ & $113.3 \pm 5.6 \%$ & $140.8 \pm 6.4 \%$ & $147.2 \pm 5.8 \%$ & $136.9 \pm 4.3 \%$ & $148.0 \pm 2.8 \%$ & $143.0 \pm 5.5 \%$ & $149.9 \pm 5.6 \%$ \\
\hline 120 & $121.2 \pm 6.8 \%$ & $98.2 \pm 4.2 \%{ }^{*}$ & $100.5 \pm 6.1 \% *$ & $129.2 \pm 3.2 \%$ & $132.4 \pm 7.2 \%$ & $101.7 \pm 4.1 \% *$ & $139.0 \pm 3.5 \%$ & $102.2 \pm 4.6 \% *$ & $103.4 \pm 6.2 \%{ }^{*}$ \\
\hline
\end{tabular}

Shown is a comparison of mean fEPSP amplitude from acute hippocampal slices perfused with vehicle $(n=4), \operatorname{AMD}(n=5), \mathrm{CH}(n=4)$, WASP-1 alone $(n=6)$, AMD + WASP- $(n=4), \mathrm{CH}+$ WASP- $1(n=5)$, FOXY-5 alone $(n=6)$, AMD + FOXY-5 $(n=4)$, or CH + FOXY-5 $(n=4)$. Data show the percent increase of fEPSP amplitude versus baseline at 30, 60, and 120 after HFS.

*Significant differences compared with vehicle treatment.

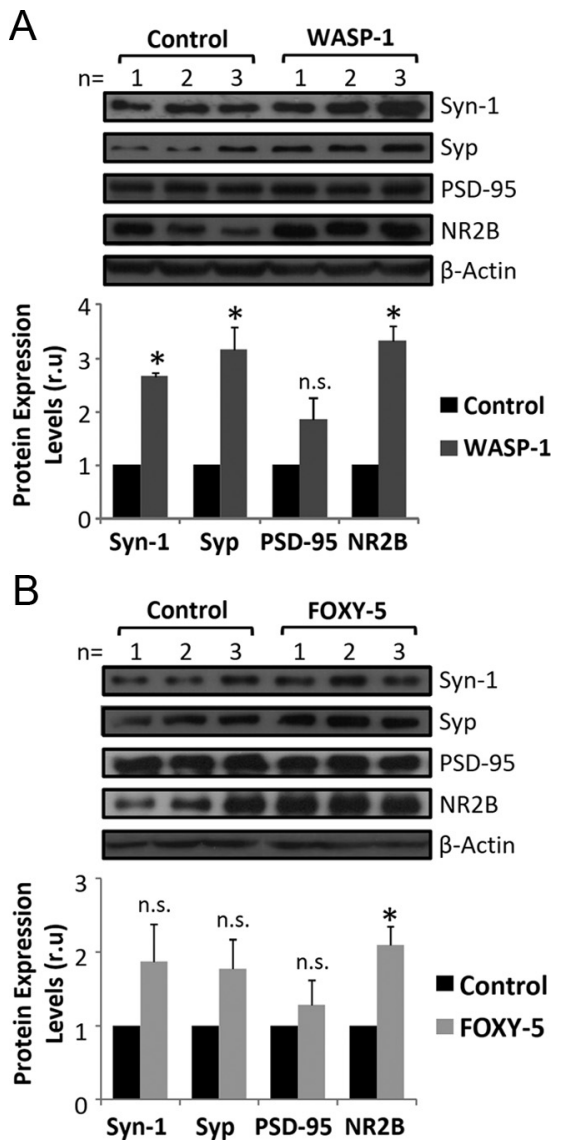

Figure 5. Wnt activators increase hippocampal synaptic protein levels in adult wild-type mice. $\boldsymbol{A}, \boldsymbol{B}$, Immunoblotting of presynaptic (Syn-1 and Syp) and postsynaptic (PSD-95 and NR2B) proteins. $\boldsymbol{A}$, Top, Western blot of hippocampal homogenates from WASP-1 $(n=3)$ and control $(n=3)$ mice. Bottom, Quantification of protein band intensities after $\beta$-actin normalization. Graphic shows fold increase versus control. $\boldsymbol{B}$, Top, Western blot of hippocampal homogenates from FOXY-5 $(n=3)$ and control $(n=3)$ mice. Bottom, Quantitative analysis as described in $\boldsymbol{A}$. n.S., No significant differences.

$\alpha_{7}$-nicotinic acetylcholine receptor $\left(\alpha_{7}\right.$-nAChR), SV2, Synaptotagmin (Syt; Farias et al., 2007), Synapsin-1 (Syn-1) (Hall et al., 2000), and Synaptophysin (Syp) (Cerpa et al., 2008), whereas $W n t-7 b$ increases the number of clusters of Bassoon, VAMP2, and Syt (Ahmad-Annuar et al., 2006). Conversely, the noncanonical Wnt ligand Wnt-5a promotes the clustering of postsynaptic proteins as the $\mathrm{GABA}_{\mathrm{A}}$ receptor (Cuitino et al., 2010) or postsynaptic density protein-95 (PSD-95; Farias et al., 2009). Here, we studied whether chronic treatment with WASP-1 and FOXY-5 also has an effect on hippocampal synaptic proteins levels of adult mice. As shown in Figure $5 A$, WASP-1 treatment significantly enhanced the levels of the presynaptic proteins Syp and Syn- 1 and the postsynaptic protein NMDA receptor subunit
2B (NR2B) without affecting the levels of PSD-95. Instead, FOXY -5 treatment increased the levels of NR2B protein, but did not induce changes on the levels of PSD-95 or any assayed presynaptic protein (Fig. $5 B$ ). These results indicate that chronic activation of Wnt signaling might modulate synaptic structure of presynaptic and postsynaptic sites in vivo. Even though FOXY-5 treatment only affected the levels of the postsynaptic protein NR2B, the activation of canonical Wnt signaling by WASP-1 (Fig. $1 A$ ) raised the levels not only of presynaptic but also postsynaptic proteins. This dual effect on the synaptic structure could be responsible for the functional changes observed in the hippocampal CA3-CA1 synapses (Figs. 2, 3).

\section{WASP-1 and FOXY-5 rescue cognitive impairment in adult APP/PS1 mice}

Several studies suggest that Wnt signaling is involved in AD pathology (Zhang et al., 1998; Caricasole et al., 2004; De Ferrari et al., 2007; Toledo and Inestrosa, 2010). Moreover, numerous in vitro studies have shown that activation of Wnt signaling has a neuroprotective effect against $\mathrm{A} \beta$-induced synaptic damage (De Ferrari et al., 2003; Alvarez et al., 2004; Cerpa et al., 2010; Shruster et al., 2011). To evaluate the effect of in vivo Wnt signaling activation on cognitive impairment associated with $\mathrm{AD}$, we used APP/PS1 double-transgenic mice that coexpress mutant APPswe (K595N/M596L) and PSEN1 (exon 9 deletion of the presenilin-1 gene). The episodic memory performance in APP/PS1 mice begins to be affected as early as 3 months of age, whereas spatial memory is impaired only after 6 months (Trinchese et al., 2004). Therefore, to address whether WASP- 1 and FOXY- 5 treatments can rescue nonspatial episodic memory decline, we examined behavioral performance of 7-month-old APP/PS1 mice in the novel object recognition task. Exploration time during familiarization of the mice to the objects did not differ significantly among control, WASP-1-, and FOXY-5-treated APP/PS1 mice (Fig. 6A). Upon introduction of a novel object, WASP-1- and FOXY-5-treated APP/PS1 mice exhibited stronger preference for the novel object than control APP/PS1 mice (Fig. 6B). Remarkably, performance of WASP-1- and FOXY-5-treated mice is similar to that of WT animals (Fig. 6B), indicating that chronic activation of Wnt signaling successfully overcame memory impairment in adult APP/PS1 mice. Even though WASP-1- and FOXY-5-treated APP/PS1 mice almost reach control WT performance, these animals still exhibit lower preference index than treated WT mice (Fig. 6C).

Defective learning and memory in APP/PS1 mice has been associated with synaptic plasticity deficits (Trinchese et al., 2004). Indeed, APP/PS1 mice show decreasing basal synaptic transmission at late ages of 5-6 months, whereas hippocampal LTP beginning to impair as early as 3 months (Trinchese et al., 2004). Therefore, we next investigated whether WASP-1 and FOXY-5 treatment could also rescue synaptic function deficit in 7-month- 

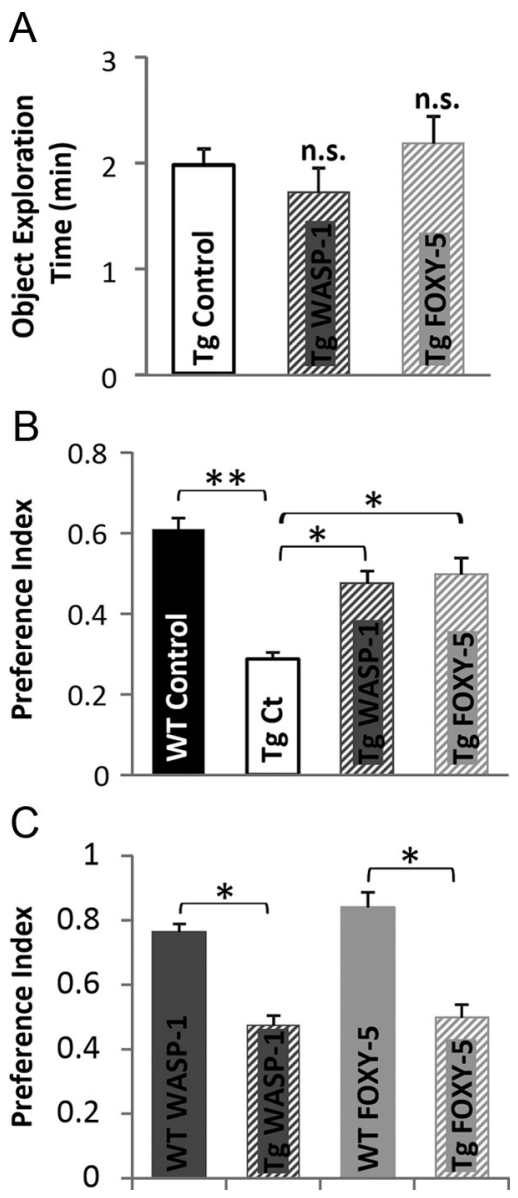

Figure 6. Wnt activators rescue memory impairment in adult APP/PS1 mice. $\boldsymbol{A}-\boldsymbol{C}$, Behavioral performance of APP/PS1 mice treated with WASP-1 $(n=7)$, FOXY-5 $(n=6)$, and control $(n=7)$ evaluated by the novel object recognition test. $A$, Total object exploration time during acquisition memory phase of the test, showing no significant differences (n.s.) among groups. $\boldsymbol{B}$, Preference index for the novel object during retention memory phase of the test. Comparison among control WT mice and the APP/PS1 groups. C, Comparison of preference index for the novel object between WT and APP/PS1 mice treated with WASP-1 or FOXY- 5 during retention memory phase of the test. Tg, Transgenic APP/PS1 mice; Ct, control.

old APP/PS1 mice. We initially looked for changes of basal synaptic transmission between CA3-CA1 neurons in hippocampal slices of APP/PS1 mice treated with WASP-1 and FOXY-5. We found that synaptic strength in WASP-1- and FOXY-5-treated mice is increased compared with control mice (Fig. $7 B$ ), because larger synaptic responses are evocated by an equal fiber volley amplitude (Fig. 7A). In Figure $7 C$, representative traces of fEPSP show changes in the amplitude induced by WASP-1 and FOXY-5 treatments compared with APP/PS1 and WT control mice. With these treatments, an enhanced input/output correlation is observed upon increasing stimulus intensity (Fig. 7D). For the highest intensity assayed $(900 \mu \mathrm{A})$, the mean fEPSP amplitude registered for APP/PS1 control ( $n=8$ slices $/ 6$ mice) mice was $3.50 \pm 0.3 \mathrm{mV}$, whereas for WT control $(n=10$ slices $/ 7$ mice $)$ mice, it was $3.84 \pm 0.28 \mathrm{mV}$, showing no significant differences between APP/PS1 and WT control mice. Notably, fEPSP amplitude in WASP-1- $(n=8$ slices $/ 5$ mice $)$ and FOXY $-5(n=8$ slices/4 mice)-treated animals significantly enhanced up to $4.54 \pm 0.30$ and $4.72 \pm 0.26 \mathrm{mV}$, respectively. Even though we found no differences in the input/output relations of APP/PS1 and WT control mice, both WASP-1 and FOXY-5 treatments significantly improved basal excitatory synaptic strength in APP/
PS1 mice. Conversely, the mean fiber volley amplitude was significantly decreased by WASP-1 and FOXY-5 treatment (Fig. $7 E$ ), indicating that fewer synaptic fibers were activated by the same stimuli. This decrease in the fiber volley amplitude induced by WASP-1 and FOXY-5 treatments reached values near to those of the WT mice. These data suggest that WASP-1 and FOXY-5 treatments effectively improve basal excitatory synaptic transmission in APP/PS1 mice.

Because LTP is reduced in the adult APP/PS1 mouse (Trinchese et al., 2004), we studied next the ability of WASP-1 and FOXY-5 treatments to undergo plastic changes on impaired hippocampal synapses of 7-month-old APP/PS1 mice. In Figure $8 A$, representative wave form changes of fEPSP before and after HFS are shown for the control WT ( $n=10$ slices $/ 7$ mice $)$ and WASP-1 $(n=8$ slices $/ 5$ mice), FOXY -5 ( $n=8$ slices $/ 4$ mice $)$ and control ( $n=10$ slices/ 6 mice) APP/PS1 groups. As shown in Figure $8 B$, WASP-1 and FOXY-5 consistently increased the LTP magnitude of APP/PS1-treated mice compared with APP/PS1 control mice. Interestingly, this induced enhancement of synaptic potentiation was maintained for $>1 \mathrm{~h}$ after the application of the HFS protocol (Fig. $8 B, C$ ). Indeed, the LTP magnitude at 30 or 70 min after HFS was higher in WASP-1 (122.00 $\pm 3.22 \%$ and $120.82 \pm 3.08 \%$, respectively) and FOXY -5 (130.95 $\pm 4.05 \%$ and $127.04 \pm 4.84 \%$, respectively) mice than in control (101.28 \pm $5.82 \%$ and $100.28 \pm 4.62 \%$ respectively) APP/PS1 mice (Fig. $8 \mathrm{C}$ ). The analysis of fEPSP amplitudes at 30 and $70 \mathrm{~min}$ after induction of LTP reveals that WASP-1 and FOXY-5 treatments significantly rescue LTP deficit observed in APP/PS1 control mice, reaching values similar to those shown by WT $(121.54 \pm 2.24 \%$ at $30 \mathrm{~min}$ and $127.75 \pm 1.60 \%$ at $70 \mathrm{~min}$ after HFS) mice (Fig. $8 \mathrm{C}$ ). These results indicate that loss of synaptic function in AD pathology could be recovered by WASP- 1 and FOXY -5 treatments. However, a comparison of the mean LTP magnitude between APP/PS1 and WT mice treated either with WASP-1 (Fig. 8D) or FOXY-5 (Fig. 8E) shows that rescue of LTP impairment in APP/ PS1 mice is not sufficient to reach those levels exhibited by WTtreated animals.

Together, our findings suggest that chronic activation of Wnt signaling in adult APP/PS1 mice could reverse the hippocampusdependent memory deficits and rescue hippocampal synaptic impairments. Therefore, we propose $W n t$ activators as a promising therapy for $\mathrm{AD}$ treatment.

\section{Discussion}

Even though in vitro data suggest that Wnt signaling participates in synaptic plasticity of the adult brain (Inestrosa and Arenas, 2010; Budnik and Salinas, 2011; Rosso and Inestrosa, 2013), until now, there were no in vivo studies that investigated whether Wnt signaling has a role in the adult hippocampal cognitive function. Here, we have provided the first evidence that in vivo activation of Wnt signaling enhances synaptic plasticity and improves memory in adult mice. Moreover, we found that activation of Wnt signaling can rescue synaptic and memory impairments in adult APP/ PS1 mice. These results suggest that Wnt signaling could have a role in synaptic function that underlies memory in the adult brain.

\section{Wnt signaling could be an important pathway regulating memory of adults}

The role of Wnt signaling in adult memory has been suggested previously (Oliva et al., 2013). Recent studies have implicated Wnt signaling in the amygdala-dependent fear memory consolidation and the regulation of hippocampal long-term information 
A

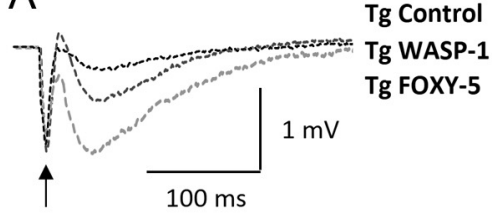

C
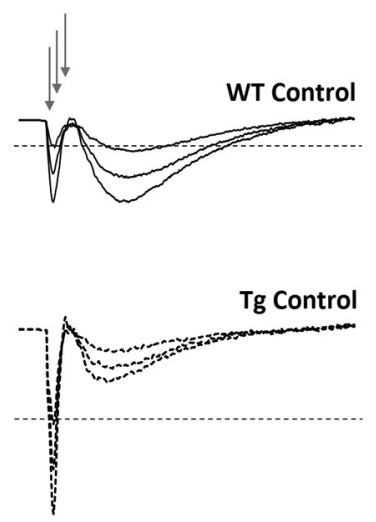

Tg WASP-1
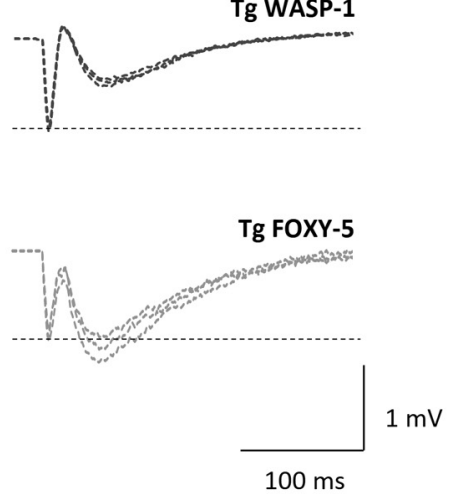

$\mathrm{B}$

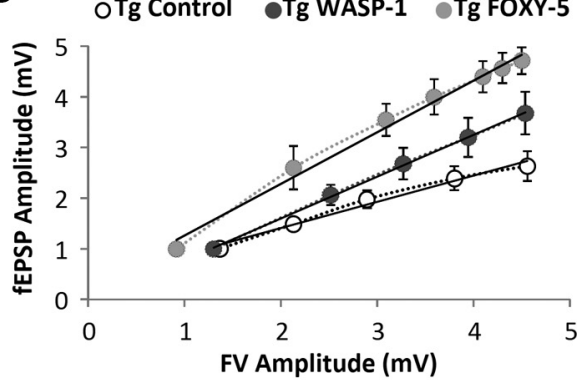

D

OTg Control •Tg WASP-1 ๑Tg FOXY-5 •WT Control

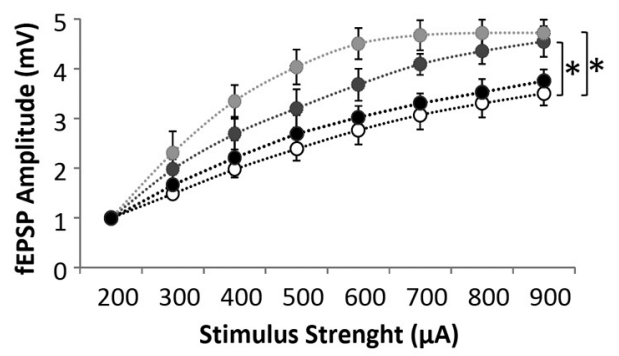

$\mathrm{E}$ OTg Control @Tg WASP-1 eTg FOXY-5 @WT Control

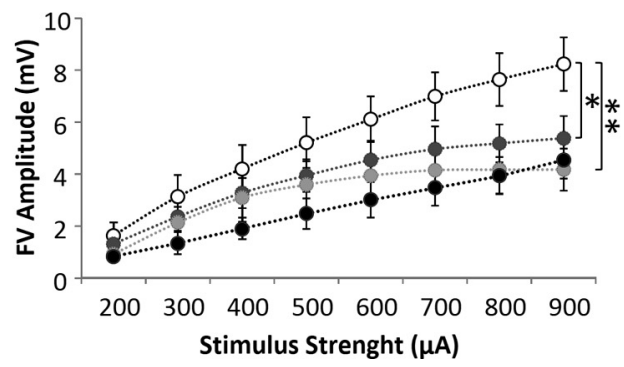

Figure 7. Wnt activators enhance basal excitatory synaptic transmission in adult APP/PS1 mice. $\boldsymbol{A}-\boldsymbol{E}$, Field recordings of hippocampal slices from APP/PS1 animals treated with WASP-1 $(n=8)$, FOXY-5 $(n=8)$, or control $(n=8)$. $\boldsymbol{A}$, Representative waveforms of fEPSP amplitude for given fiber volley (FV) amplitude (black arrow). $\boldsymbol{B}$, Correlation of fEPSP and FV amplitudes for each group. Black lines are the regression line for fEPSP (output) and FV (input). The correlation coefficients $\left(R^{2}\right)$ in the control, WASP-1, and FOXY-5 mice were $0.9829,0.9993$, and 0.9893 , respectively. C, Average traces of fEPSP at three different intensities of stimulation (gray arrows). Dotted lines indicate FV amplitude of $1 \mathrm{mV}$. D, Plot of fEPSP amplitude versus stimulus intensity (from 200 to $900 \mu \mathrm{A}$ ). E, Plot of FV amplitude versus stimulus intensity (from 200 to $900 \mu \mathrm{A}$ ). Tg, Transgenic APP/PS1 mice.

storage (Maguschak and Ressler, 2011; Tabatadze et al., 2012). In fact, the infusion of Dkk1 into the amygdala has shown to impair fear memory consolidation (Maguschak and Ressler, 2011), whereas infusion of Dkk1 into the hippocampus impairs object recognition memory consolidation (Fortress et al., 2013). In addition, other proteins of Wnt signaling have been involved in memory processing. For example, adenomatous polyposis coli (APC) heterozygous knock-out mice display age-dependent working memory deficits (Koshimizu et al., 2011).

Here, we provide evidence that Wnt signaling also enhances short-term information storage of both spatial and nonspatial memories in adult mice. Remarkably, we found that it is not only the activation of $W n t / \beta$-catenin signaling that has an effect on memory consolidation, as has been reported previously (Maguschak and Ressler, 2008; Fortress et al., 2013); the activation of noncanonical Wnt signaling by FOXY-5 has a similar effect.
Wnt signaling is involved in synaptic plasticity of the adult brain

LTP, an activity-dependent enhancement of synaptic strength, is considered one of the physiological mechanisms that underlie learning and memory in the hippocampus (Citri and Malenka, 2008). Recent studies have shown that activation of Wnt signaling facilitates hippocampal LTP, whereas blockade of this signaling impairs it (Chen et al., 2006; Cerpa et al., 2011). Furthermore, Wnt signaling activation also increases excitatory synaptic transmission in hippocampal neurons (Beaumont et al., 2007; Cerpa et al., 2008; Varela-Nallar et al., 2010). These findings suggest a role for Wnt signaling in the regulation of synaptic plasticity on mature synapses, but in vivo studies are still required. Here, we present evidence that in vivo activation of Wnt signaling into the adult hippocampus results in an enhancement of basal excitatory synaptic efficacy and LTP magnitude.

Previously, we showed that both canonical and noncanonical $W n t$ ligands are able to increase hippocampal excitatory synaptic transmission (Cerpa et al., 2008; Varela-Nallar et al., 2010; Cerpa et al., 2011). Consistent with this observation, we show here that in vivo activation of canonical and noncanonical Wnt signaling equally enhance basal excitatory transmission of adult mice. Even though canonical and noncanonical Wnt ligands have the same effect on excitatory synaptic transmission, it seems that different mechanisms are involved in each effect. For example, canonical Wnt-7a ligand modulates presynaptic vesicle recycling and neurotransmitter release through a mechanism that diverges from the transcription-dependent pathway (Cerpa et al., 2008), whereas noncanonical Wnt-5a ligand regulates the postsynaptic structure by promoting the formation of new spines or increasing the size of preexisting ones in a $\mathrm{Ca}^{2+}$-dependent manner (Varela-Nallar et al., 2010).

In addition, it has been reported that either canonical Wnt-3a or noncanonical Wnt-5a ligands facilitates the induction of LTP (Chen et al., 2006; Cerpa et al., 2011). Here, we compared the effect of chronic activation of both the canonical and noncanonical Wnt pathways on hippocampal LTP. Our data show that although both WASP-1 and FOXY-5 treatments increase the LTP magnitude, FOXY-5 has a stronger effect than WASP-1. It is possible that these differences arise from a dissimilar mechanism involved in the activation of the pathway and/or in the effects downstream. Indeed, although FOXY-5 activates noncanonical Wnt signaling directly (Safholm et al., 2006), WASP-1 requires the presence of Wnt-3a ligand to synergistically activate canonical Wnt signaling (Beaumont et al., 2007), suggesting that endogenous Wnt-3a ligand is locally released at the hippocampus and al- 
lows WASP-1 to exert its effects. In addition, the effects of canonical and noncanonical Wnt signaling on synaptic plasticity occur through different mechanisms. Therefore, canonical Wnt ligands could regulate synaptic plasticity by influencing neurotransmitters release through modulation of the interaction between proteins of the Wnt pathway and molecules implicated in synaptic plasticity and memory formation. Interactions between $\beta$-catenin and cadherins (Maguschak and Ressler, 2008), Dvl and Syt (Kishida et al., 2007), or APC and presynaptic $\alpha_{7}$-nAChRs (Farias et al., 2007) have been described previously. Conversely, noncanonical Wnt ligands could modulate synaptic plasticity by inducing a rapid increase in intracellular $\mathrm{Ca}^{2+}$ concentrations and the activation of CaMKII (VarelaNallar et al., 2010; Cerpa et al., 2011).

Moreover, the effects of Wnt signaling on synaptic plasticity are also mediated by the modulation of gene expression. Indeed, we found here that the effect of WASP-1 on 1-LTP depends on synthesis of new proteins, but does not depend on new RNA synthesis, whereas the effect of FOXY-5 on 1-LTP requires both transcription and translation (Table 1). After the categorization of LTP in LTP1, LTP2, and LTP3 in accordance with the persistence and the mechanisms involved in each form (Racine et al., 1983; Raymond and Redman, 2006), WASP-1 seems to elicit LTP2, which is only dependent on protein synthesis from preexisting mRNA located in the dendrites. Conversely, FOXY-5-induced LTP is consistent with LTP3, because both protein translation and gene transcription are required for 1-LTP maintenance. These results suggest that the mechanisms elicited by canonical and noncanonical Wnt signaling to influence hippocampal l-LTP have different requirements.

\section{Wnt signaling is implicated in the remodeling of synaptic structures}

Because structural modifications of synaptic sites are associated and might be required for synaptic plasticity and memory (De Roo et al., 2008), Wnt signaling could therefore play a role in synaptic remodeling of mature synapses. Supporting this hypothesis, our results show that in vivo activation of Wnt signaling induces an improvement on hippocampal cognitive function in adult mice that correlates with an increase in synaptic protein expression. Previously, it was proposed that canonical Wnt ligands selectively modulate presynaptic sites, whereas noncanonical Wnt ligands would modulate the postsynaptic structure (Cerpa et al., 2009). However, we found here that activation of canonical Wnt signaling could change the levels of synaptic proteins at both presynaptic and postsynaptic sites. This dual effect has been previously reported for canonical Wnt-7a ligand: although a role for $W n t-7 a$ ligand in promoting the clustering of several presynaptic proteins has been demonstrated (Farias et al.,
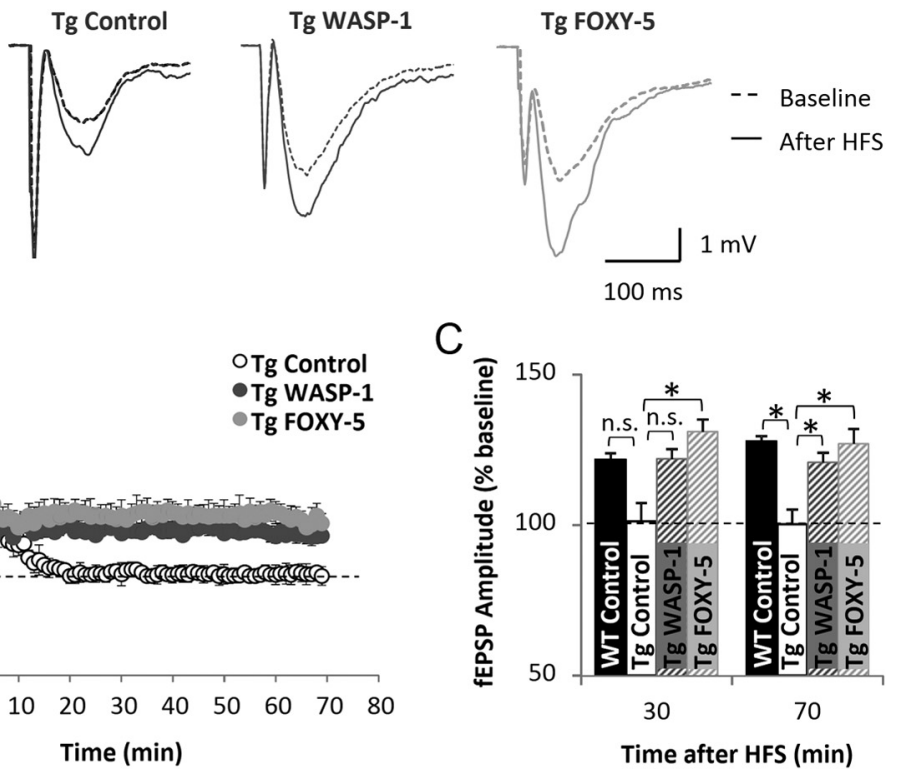

E

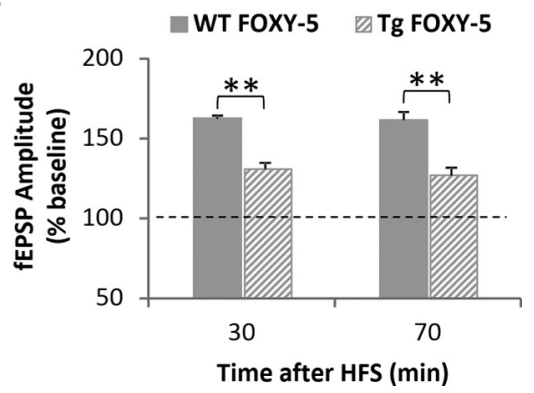

Time after HFS (min)
Tg WASP-1

Tg FOXY-5
Tg Control C differences. $\boldsymbol{D}$, Comparison between WT and APP/PS1 mice treated with WASP-1. E, Comparison between WT and APP/PS1 mice treated with FOXY-5. Tg, Transgenic APP/PS1 mice.

2007; Cerpa et al., 2008), recent evidence suggests that Wnt-7a ligand also increases the density and maturity of dendritic spines (Gogolla et al., 2009; Ciani et al., 2011). This dual effect could be explained by assuming that a single Wnt ligand can activate different signaling branches. Indeed, Wnt-3a ligand activates both canonical and noncanonical pathways, but the type of Wnt signaling activated depends on ligand concentration (Nalesso et al., 2011).

\section{Wnt signaling dysfunction in $\mathrm{AD}$}

There are several components of Wnt pathway that are altered in $\mathrm{AD}$ (Moon et al., 2004; Inestrosa et al., 2012). $\beta$-catenin levels in AD brains are considerably downregulated (Zhang et al., 1998), whereas the expression of Dkk1 is upregulated (Caricasole et al., 2004) compared with healthy brains. Moreover, a recent study has shown that $\mathrm{A} \beta$-induced Dkk1 expression depends on clusterin, a susceptibility factor for late-onset AD (Killick et al., 2012). In addition, several in vitro studies have demonstrated a relationship between loss of $W n t$ signaling and $\mathrm{A} \beta$ neurotoxicity (Alvarez et al., 2004; Purro et al., 2012). In fact, $A \beta$ has shown to inhibit 
$W n t / \beta$-catenin signaling by binding directly to several Frizzled receptors (Magdesian et al., 2008).

The activation of canonical Wnt signaling protects against $\mathrm{A} \beta$-dependent cytotoxic effects in hippocampal cultured neurons (Alvarez et al., 2004) and reduces spatial memory deficit and $\mathrm{A} \beta$ deposition in APP/PS1 mice (Toledo and Inestrosa, 2010). In addition, the activation of noncanonical Wnt signaling by $W n t-5 a$ ligand prevents $\mathrm{A} \beta$-induced depression of excitatory synaptic transmission in hippocampal slices (Cerpa et al., 2010).

Here, we add evidence that activation of both canonical and noncanonical Wnt signaling enhances basal synaptic transmission and rescues hippocampal LTP impairment in adult APP/PS1 mice. Moreover, in vivo activation of Wnt signaling also improved short-term memory of APP/PS1 mice, as has been proposed in other models of memory deficits (Guo et al., 2012; King et al., 2013). However, from our results, it is not possible to conclude whether rescue of memory and synaptic deficits by activation of Wnt signaling occurs by a direct action on mechanisms impaired by $\mathrm{A} \beta$ or if it is an additive effect independent of $\mathrm{A} \beta$-induced damage. More studies are required to clarify this issue.

\section{References}

Ahmad-Annuar A, Ciani L, Simeonidis I, Herreros J, Fredj NB, Rosso SB, Hall A, Brickley S, Salinas PC (2006) Signaling across the synapse: a role for Wnt and Dishevelled in presynaptic assembly and neurotransmitter release. J Cell Biol 174:127-139. CrossRef Medline

Alvarez AR, Godoy JA, Mullendorff K, Olivares GH, Bronfman M, Inestrosa NC (2004) Wnt-3a overcomes beta-amyloid toxicity in rat hippocampal neurons. Exp Cell Res 297:186-196. CrossRef Medline

Anderton BH, Dayanandan R, Killick R, Lovestone S (2000) Does dysregulation of the Notch and wingless/Wnt pathways underlie the pathogenesis of Alzheimer's disease? Mol Med Today 6:54-59. CrossRef Medline

Arrázola MS, Varela-Nallar L, Colombres M, Toledo EM, Cruzat F, Pavez L, Assar R, Aravena A, González M, Montecino M, Maass A, Martínez S, Inestrosa NC (2009) Calcium/calmodulin-dependent protein kinase type IV is a target gene of the Wnt/beta-catenin signaling pathway. J Cell Physiol 221:658-667. CrossRef Medline

Beaumont V, Thompson SA, Choudhry F, Nuthall H, Glantschnig H, Lipfert L, David GR, Swain CJ, McAllister G, Munoz-Sanjuan I (2007) Evidence for an enhancement of excitatory transmission in adult CNS by Wnt signaling pathway modulation. Mol Cell Neurosci 35:513-524. CrossRef Medline

Bevins RA, Besheer J (2006) Object recognition in rats and mice: a one-trial non-matching-to-sample learning task to study 'recognition memory'. Nat Protoc 1:1306-1311. CrossRef Medline

Bonansco C, Couve A, Perea G, Ferradas CÁ, Roncagliolo M, Fuenzalida M (2011) Glutamate released spontaneously from astrocytes sets the threshold for synaptic plasticity. Eur J Neurosci 33:1483-1492. CrossRef Medline

Boonen RA, van Tijn P, Zivkovic D (2009) Wnt signaling in Alzheimer's disease: up or down, that is the question. Ageing Res Rev 8:71-82. CrossRef Medline

Budnik V, Salinas PC (2011) Wnt signaling during synaptic development and plasticity. Curr Opin Neurobiol 21:151-159. CrossRef Medline

Caricasole A, Copani A, Caraci F, Aronica E, Rozemuller AJ, Caruso A, Storto M, Gaviraghi G, Terstappen GC, Nicoletti F (2004) Induction of Dickkopf-1, a negative modulator of the Wnt pathway, is associated with neuronal degeneration in Alzheimer's brain. J Neurosci 24:6021-6027. CrossRef Medline

Cerpa W, Godoy JA, Alfaro I, Farías GG, Metcalfe MJ, Fuentealba R, Bonansco C, Inestrosa NC (2008) Wnt-7a modulates the synaptic vesicle cycle and synaptic transmission in hippocampal neurons. J Biol Chem 283:5918-5927. CrossRef Medline

Cerpa W, Toledo EM, Varela-Nallar L, Inestrosa NC (2009) The role of Wnt signaling in neuroprotection. Drug News Perspect 22:579-591. CrossRef Medline

Cerpa W, Farías GG, Godoy JA, Fuenzalida M, Bonansco C, Inestrosa NC (2010) Wnt-5a occludes Abeta oligomer-induced depression of glutama- tergic transmission in hippocampal neurons. Mol Neurodegener 5:3. CrossRef Medline

Cerpa W, Gambrill A, Inestrosa NC, Barria A (2011) Regulation of NMDAreceptor synaptic transmission by Wnt signaling. J Neurosci 31:94669471. CrossRef Medline

Chen G, Chen KS, Knox J, Inglis J, Bernard A, Martin SJ, Justice A, McConlogue L, Games D, Freedman SB, Morris RG (2000) A learning deficit related to age and beta-amyloid plaques in a mouse model of Alzheimer's disease. Nature 408:975-979. CrossRef Medline

Chen J, Park CS, Tang SJ (2006) Activity-dependent synaptic Wnt release regulates hippocampal long term potentiation. J Biol Chem 281:11910 11916. CrossRef Medline

Chen JT, Lu DH, Chia CP, Ruan DY, Sabapathy K, Xiao ZC (2005) Impaired long-term potentiation in c-Jun $\mathrm{N}$-terminal kinase 2-deficient mice. J Neurochem 93:463-473. CrossRef Medline

Ciani L, Salinas PC (2005) WNTs in the vertebrate nervous system: from patterning to neuronal connectivity. Nat Rev Neurosci 6:351-362. CrossRef Medline

Ciani L, Boyle KA, Dickins E, Sahores M, Anane D, Lopes DM, Gibb AJ, Salinas PC (2011) Wnt7a signaling promotes dendritic spine growth

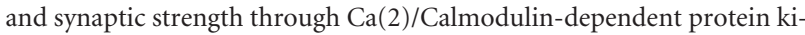
nase II. Proc Natl Acad Sci U S A 108:10732-10737. CrossRef Medline

Citri A, Malenka RC (2008) Synaptic plasticity: multiple forms, functions, and mechanisms. Neuropsychopharmacology 33:18-41. CrossRef Medline

Cuitino L, Godoy JA, Farías GG, Couve A, Bonansco C, Fuenzalida M, Inestrosa NC (2010) Wnt-5a modulates recycling of functional GABAA receptors on hippocampal neurons. J Neurosci 30:8411-8420. CrossRef Medline

De Ferrari GV, Inestrosa NC) (2000) Wnt signaling function in Alzheimer's disease. Brain Res Brain Res Rev 33:1-12. CrossRef Medline

De Ferrari GV, Chacón MA, Barría MI, Garrido JL, Godoy JA, Olivares G, Reyes AE, Alvarez A, Bronfman M, Inestrosa NC (2003) Activation of Wnt signaling rescues neurodegeneration and behavioral impairments induced by beta-amyloid fibrils. Mol Psychiatry 8:195-208. CrossRef Medline

De Ferrari GV, Papassotiropoulos A, Biechele T, Wavrant De-Vrieze F, Avila ME, Major MB, Myers A, Sáez K, Henríquez JP, Zhao A, Wollmer MA, Nitsch RM, Hock C, Morris CM, Hardy J, Moon RT (2007) Common genetic variation within the low-density lipoprotein receptor-related protein 6 and late-onset Alzheimer's disease. Proc Natl Acad Sci U S A 104: 9434-9439. CrossRef Medline

De Roo M, Klauser P, Garcia PM, Poglia L, Muller D (2008) Spine dynamics and synapse remodeling during LTP and memory processes. Prog Brain Res 169:199-207. CrossRef Medline

Farías GG, Vallés AS, Colombres M, Godoy JA, Toledo EM, Lukas RJ, Barrantes FJ, Inestrosa NC (2007) Wnt-7a induces presynaptic colocalization of alpha 7-nicotinic acetylcholine receptors and adenomatous polyposis coli in hippocampal neurons. J Neurosci 27:5313-5325. CrossRef Medline

Farías GG, Alfaro IE, Cerpa W, Grabowski CP, Godoy JA, Bonansco C, Inestrosa NC (2009) Wnt-5a/JNK signaling promotes the clustering of PSD-95 in hippocampal neurons. J Biol Chem 284:15857-15866. CrossRef Medline

Farías GG, Godoy JA, Cerpa W, Varela-Nallar L, Inestrosa NC (2010) Wnt signaling modulates pre- and postsynaptic maturation: therapeutic considerations. Dev Dyn 239:94-101. CrossRef Medline

Fortress AM, Schram SL, Tuscher JJ, Frick KM (2013) Canonical Wnt signaling is necessary for object recognition memory consolidation. J Neurosci 33:12619-12626. CrossRef Medline

Garrido JL, Godoy JA, Alvarez A, Bronfman M, Inestrosa NC (2002) Protein kinase $\mathrm{C}$ inhibits amyloid beta peptide neurotoxicity by acting on members of the Wnt pathway. FASEB J 16:1982-1984. CrossRef Medline

Gogolla N, Galimberti I, Deguchi Y, Caroni P (2009) Wnt signaling mediates experience-related regulation of synapse numbers and mossy fiber connectivities in the adult hippocampus. Neuron 62:510-525. CrossRef Medline

Guo W, Murthy AC, Zhang L, Johnson EB, Schaller EG, Allan AM, Zhao X (2012) Inhibition of GSK3beta improves hippocampus-dependent learning and rescues neurogenesis in a mouse model of fragile X syndrome. Hum Mol Genet 21:681-691. CrossRef Medline

Hall AC, Lucas FR, Salinas PC (2000) Axonal remodeling and synaptic dif- 
ferentiation in the cerebellum is regulated by WNT-7a signaling. Cell 100:525-535. CrossRef Medline

Hillen H, Barghorn S, Striebinger A, Labkovsky B, Müller R, Nimmrich V, Nolte MW, Perez-Cruz C, van der Auwera I, van Leuven F, van Gaalen M, Bespalov AY, Schoemaker H, Sullivan JP, Ebert U (2010) Generation and therapeutic efficacy of highly oligomer-specific beta-amyloid antibodies. J Neurosci 30:10369-10379. CrossRef Medline

Hooper C, Markevich V, Plattner F, Killick R, Schofield E, Engel T, Hernandez F, Anderton B, Rosenblum K, Bliss T, Cooke SF, Avila J, Lucas JJ, Giese KP, Stephenson J, Lovestone S (2007) Glycogen synthase kinase-3 inhibition is integral to long-term potentiation. Eur J Neurosci 25:81-86. CrossRef Medline

Hsia AY, Malenka RC, Nicoll RA (1998) Development of excitatory circuitry in the hippocampus. J Neurophysiol 79:2013-2024. Medline

Hu D, Serrano F, Oury TD, Klann E (2006) Aging-dependent alterations in synaptic plasticity and memory in mice that overexpress extracellular superoxide dismutase. J Neurosci 26:3933-3941. CrossRef Medline

Inestrosa NC, Montecinos-Oliva C, Fuenzalida M (2012) Wnt signaling: role in Alzheimer disease and schizophrenia. J Neuroimmune Pharmacol 7:788-807. CrossRef Medline

Inestrosa NC, Arenas E (2010) Emerging roles of Wnts in the adult nervous system. Nat Rev Neurosci 11:77-86. CrossRef Medline

Kelleher RJ 3rd, Govindarajan A, Tonegawa S (2004) Translational regulatory mechanisms in persistent forms of synaptic plasticity. Neuron 44:5973. CrossRef Medline

Killick R, Ribe EM, Al-Shawi R, Malik B, Hooper C, Fernandes C, Dobson R, Nolan PM, Lourdusamy A, Furney S, Lin K, Breen G, Wroe R, To AW, Leroy K, Causevic M, Usardi A, Robinson M, Noble W, Williamson R, et al. (2012) Clusterin regulates beta-amyloid toxicity via Dickkopf-1driven induction of the wnt-PCP-JNK pathway. Mol Psychiatry 19:8898. CrossRef Medline

King MR, Anderson NJ, Guernsey LS, Jolivalt CG (2013) Glycogen synthase kinase-3 inhibition prevents learning deficits in diabetic mice. J Neurosci Res 91:506-514. CrossRef Medline

Kishida S, Hamao K, Inoue M, Hasegawa M, Matsuura Y, Mikoshiba K, Fukuda M, Kikuchi A (2007) Dvl regulates endo- and exocytotic processes through binding to synaptotagmin. Genes Cells 12:49-61. CrossRef Medline

Koshimizu H, Fukui Y, Takao K, Ohira K, Tanda K, Nakanishi K, Toyama K, Oshima M, Taketo MM, Miyakawa T (2011) Adenomatous polyposis coli heterozygous knock-out mice display hypoactivity and agedependent working memory deficits. Front Behav Neurosci 5:85. CrossRef Medline

Magdesian MH, Carvalho MM, Mendes FA, Saraiva LM, Juliano MA, Juliano L, Garcia-Abreu J, Ferreira ST (2008) Amyloid-beta binds to the extracellular cysteine-rich domain of Frizzled and inhibits Wnt/beta-catenin signaling. J Biol Chem 283:9359-9368. CrossRef Medline

Maglio LE, Martins VR, Izquierdo I, Ramirez OA (2006) Role of cellular prion protein on LTP expression in aged mice. Brain Res 1097:11-18. CrossRef Medline

Maguschak KA, Ressler KJ (2008) Beta-catenin is required for memory consolidation. Nat Neurosci 11:1319-1326. CrossRef Medline

Maguschak KA, Ressler KJ (2011) Wnt signaling in amygdala-dependent learning and memory. J Neurosci 31:13057-13067. CrossRef Medline

Moon RT, Kohn AD, De Ferrari GV, Kaykas A (2004) WNT and betacatenin signalling: diseases and therapies. Nat Rev Genet 5:691-701. CrossRef Medline

Nalesso G, Sherwood J, Bertrand J, Pap T, Ramachandran M, De Bari C, Pitzalis C, Dell'accio F (2011) WNT-3A modulates articular chondrocyte phenotype by activating both canonical and noncanonical pathways. J Cell Biol 193:551-564. CrossRef Medline

Nusse R, Varmus H (2012) Three decades of Wnts: a personal perspective on how a scientific field developed. EMBO J 31:2670-2684. CrossRef Medline

Okun E, Griffioen K, Barak B, Roberts NJ, Castro K, Pita MA, Cheng A, Mughal MR, Wan R, Ashery U, Mattson MP (2010) Toll-like receptor 3 inhibits memory retention and constrains adult hippocampal neurogenesis. Proc Natl Acad Sci U S A 107:15625-15630. CrossRef Medline

Oliva CA, Vargas JY, Inestrosa NC (2013) Wnt signaling: role in LTP, neural networks and memory. Ageing Res Rev 12:786-800. CrossRef Medline
Park M, Shen K (2012) WNTs in synapse formation and neuronal circuitry. EMBO J 31:2697-2704. CrossRef Medline

Peineau S, Taghibiglou C, Bradley C, Wong TP, Liu L, Lu J, Lo E, Wu D, Saule E, Bouschet T, Matthews P, Isaac JT, Bortolotto ZA, Wang YT, Collingridge GL (2007) LTP inhibits LTD in the hippocampus via regulation of GSK3beta. Neuron 53:703-717. CrossRef Medline

Purro SA, Dickins EM, Salinas PC (2012) The secreted Wnt antagonist Dickkopf- 1 is required for amyloid beta-mediated synaptic loss. J Neurosci 32:3492-3498. CrossRef Medline

Racine RJ, Milgram NW, Hafner S (1983) Long-term potentiation phenomena in the rat limbic forebrain. Brain Res 260:217-231. CrossRef Medline

Raymond CR (2007) LTP forms 1, 2 and 3: different mechanisms for the "long" in long-term potentiation. Trends Neurosci 30:167-175. CrossRef Medline

Raymond CR, Redman SJ (2006) Spatial segregation of neuronal calcium signals encodes different forms of LTP in rat hippocampus. J Physiol 570:97-111. CrossRef Medline

Richter JD, Klann E (2009) Making synaptic plasticity and memory last: mechanisms of translational regulation. Genes Dev 23:1-11. CrossRef Medline

Rosso SB, Inestrosa NC (2013) WNT signaling in neuronal maturation and synaptogenesis. Front Cell Neurosci 7:103. CrossRef Medline

Säfholm A, Leandersson K, Dejmek J, Nielsen CK, Villoutreix BO, Andersson $\mathrm{T}$ (2006) A formylated hexapeptide ligand mimics the ability of Wnt-5a to impair migration of human breast epithelial cells. J Biol Chem 281: 2740-2749. CrossRef Medline

Säfholm A, Tuomela J, Rosenkvist J, Dejmek J, Härkönen P, Andersson T (2008) The Wnt-5a-derived hexapeptide Foxy-5 inhibits breast cancer metastasis in vivo by targeting cell motility. Clin Cancer Res 14:65566563. CrossRef Medline

Selkoe DJ (2001) Alzheimer's disease results from the cerebral accumulation and cytotoxicity of amyloid beta-protein. J Alzheimers Dis 3:75-80. Medline

Selkoe DJ (2002) Alzheimer's disease is a synaptic failure. Science 298:789791. CrossRef Medline

Seo J, Hong J, Lee SJ, Choi SY (2012) c-Jun N-terminal phosphorylation is essential for hippocampal synaptic plasticity. Neurosci Lett 531:14-19. CrossRef Medline

Sheng M, Sabatini BL, Südhof TC (2012) Synapses and Alzheimer's disease. Cold Spring Harb Perspect Biol 4:pii:a005777. CrossRef Medline

Shimogori T, VanSant J, Paik E, Grove EA (2004) Members of the Wnt, Fz, and Frp gene families expressed in postnatal mouse cerebral cortex. J Comp Neurol 473:496-510. CrossRef Medline

Shruster A, Eldar-Finkelman H, Melamed E, Offen D (2011) Wnt signaling pathway overcomes the disruption of neuronal differentiation of neural progenitor cells induced by oligomeric amyloid beta-peptide. J Neurochem 116:522-529. CrossRef Medline

Tabatadze N, Tomas C, McGonigal R, Lin B, Schook A, Routtenberg A (2012) Wnt transmembrane signaling and long-term spatial memory. Hippocampus 22:1228-1241. CrossRef Medline

Toledo EM, Inestrosa NC (2010) Activation of Wnt signaling by lithium and rosiglitazone reduced spatial memory impairment and neurodegeneration in brains of an APPswe/PSEN1DeltaE9 mouse model of Alzheimer's disease. Mol Psychiatry 15: 272-285,228. CrossRef Medline

Trinchese F, Liu S, Battaglia F, Walter S, Mathews PM, Arancio O (2004) Progressive age-related development of Alzheimer-like pathology in APP/ PS1 mice. Ann Neurol 55:801-814. CrossRef Medline

van Amerongen R, Nusse R (2009) Towards an integrated view of Wnt signaling in development. Development 136:3205-3214. CrossRef Medline

Varela-Nallar L, Alfaro IE, Serrano FG, Parodi J, Inestrosa NC (2010) Wingless-type family member $5 \mathrm{~A}$ (Wnt-5a) stimulates synaptic differentiation and function of glutamatergic synapses. Proc Natl Acad Sci U S A 107:21164-21169. CrossRef Medline

Varela-Nallar L, Parodi J, Farías GG, Inestrosa NC (2012) Wnt-5a is a synaptogenic factor with neuroprotective properties against Abeta toxicity. Neurodegener Dis 10:23-26. CrossRef Medline

Zhang Z, Hartmann H, Do VM, Abramowski D, Sturchler-Pierrat C, Staufenbiel M, Sommer B, van de Wetering M, Clevers H, Saftig P, De Strooper B, He X, Yankner BA (1998) Destabilization of beta-catenin by mutations in presenilin-1 potentiates neuronal apoptosis. Nature 395:698-702. CrossRef Medline 